\title{
From HRM to E-HRM: Contemporary Developments from Scholarly Work
}

\author{
Ammar Ahmed ${ }^{1, *}$ and Habil Slade Ogalo ${ }^{2}$ \\ ${ }^{1}$ Department of Business Administration, Institute of Southern Punjab, Multan, Pakistan \\ ammar.malik419@gmail.com \\ 2Business Administration Department, Arab Open University, Bahrain \\ drhabilslade@aou.org.bh \\ *Correspondence: ammar.malik419@gmail.com
}

Received: $5^{\text {th }}$ January 2019; Accepted: 17th February 2018; Published: $1^{\text {st }}$ May 2019

\begin{abstract}
The present article aims to shed light on the concept of Human Resource management. Therein, the authors have attempted to underline some of the important developments in the arena of HRM and where it leads the understanding to. The article elaborates on the growing shift from HRM to E-HRM and why it is becoming inevitable for businesses to understand and accept it. The discussion also highlights detailed explanation of the features and prospects of E-HRM and its uniqueness in comparison with traditional HRM practices. In parallel, the article also expounds on HRM as a strategic concept whilst unleashing on elements relating to technological primacy. The article aims to serve as a guideline for individuals enthusiastic to conduct scholarly work in the area of E-HRM and its strategic importance in the years to come.
\end{abstract}

Keywords: HRM; E-HRM; Technology; Contemporary HRM

\section{Introduction}

In human resource management (HRM), abrupt increase has been observed during the last few decades in the usage of modern information technologies (IT). This prompt increase consequence in the appendage of progressively futuristic management of core business process or enterprise resource planning (ERP) software designed along with technologies ground on internet that systemize as well as operate section of HRM which are connected with management. In assembling the administrative agreements and information communications, the delusion of HRM IT innovations based on internet which are generally familiar as E-HRM (see Bondarouk \& Ruel, 2009; Strohmeier, 2007), may be characterized of important economic productivity. It is asserted by some researchers that, IT based on internet is a ground breaking technology that will turn the strategy in an inevitable manner in which establishment are strengthen (Bower \& Christensen, 1995; Brynjolfsson \& Hitt, 2000). Along this perspective numerous analyst state that how an association perform HRM shifting it from being mainly administrative, to be a strategic move towards long term plane of gaining international recognition (Lepak \& Snell, 1998; Shrivastava \& Shaw, 2003).

This organizational technically change role of HRM is root on nation that how associations are organized is powered by the use of information. The operating HRM functions are now well focusing on more complicated, judgmental and responsive tasks, because of the attention paid towards the

Ammar Ahmed and Habil Slade Ogalo, " From HRM to E-HRM: Contemporary Developments from Scholarly Work", $\underline{\text { Annals }}$ of Contemporary Developments in Management \& HR (ACDMHR), Print ISSN: 2632-7686, Online ISSN: 2632-7694, pp. 1-6, Vol. 1, No. 1, 1st May 2019, Published by International Association of Educators and Researchers (IAER), DOI: 10.33166/ACDMHR.2019.01.001, Available: http://acdmhr.theiaer.org/archive/v1/v1n1/p1.html. 
modification of decisions, the advancement of managerial tasks, and highly access in the increasing distributive data. In this regard, HRM jobs are highly skilful as new progressive technological effects are being adaptive (Ahmed, Majid \& Zin, 2026; Brynjolfsson \& Hitt, 2000; Liang \& Marler, 2012). An alternative perspective fulfilled this view. In this perspective an important role is played by strategic managers and choices are based on how much technology is helpful for an organization in obtaining long-term or planned objectives (Barley, 1986). From this point of view, the strategic outcomes and management intention towards organizational change is when e-HRM is selected and the way it is restructured in organization (Ruel, Bondarouk \& Parry, 2017; Reddington and Martin 2010; Marler, 2009). In this connection, planned result of long-term decisions related to the ways of delivering HRM services are the origination of e-HRM in an institution. Most of the time, the organized results are depicted for providing the HRM services in a more efficient way rather than the transformation of HRM jobs in to long term prime functions (Ahmed, Khalid, Ammar \& Shah; Marler, 2009).

In this research, we examine the indications for HRM ground on long term strategy, underlying these two aspects for deep understanding into the junction of information technology and tactical firm processes. Is technological change a forerunner of strategic HRM as few proposed or is information technology is a simple mechanism for the accomplishment of strategic planning in which the employment of E-HRM is proceeds by HR strategy (c.f. Marler, 2009)? For presenting a substantial assessment of these competitive perspective and upshots, a massive Dataset of HR corporation situated in North America, Europe, Australia, and New Zealand is proven very lucrative.

This paper develops through providing definition of foremost conceptual constructs. Accordingly, it gives a detail account of the challenging hypothetical framework and associated hypotheses.

\section{E-HRM and HRM}

As technology has both physical and operating attributes therefore, it is very challenging to turn up that describing and measuring E-HRM and information technology (Orlikowski \& Scott, 2008) Therefore, information technology is a body containing physical components (e.g. hardware, software and communication network infrastructure), however differ from individuals but the belief is that in organizational works physical technology has no value if it is not using by an individual. (Marler \& Fisher, 2013). Consequently, in this exploration E-HRM composed of particularly arranged parts of computer hardware, software, and electronically working resources of computer, which helps in developing actual HRM activities (uses of policies and resources) interrelating and benchmarking sole and grouped data, operating and performing information and imparting in or outside the bonds of an organization. E-HRM institute is differs from the standard of physical appearance and the utilization of the point which help in increasing the level of individual coordination's and business that stores HR data at group level, produces HR statistics and dispense access to HR data and statistics despite the limitations of horizontal, vertical and geographical differences. Variations in the capabilities of organization represented by the changes in E-HRM for providing support, through using information of technological communication resources to the increasing and automated individual group dealings involving communication, formation, and storage of HRM data.

\section{HRM as a Strategic Concept}

The strategic HRM has been defined as "the pattern of planned human resource deployments and activities intended to enable an organization to achieve its goals" (Wright \& McMahan, 1992, p.298). The definition includes the configurations of human resources as forms of activities which with the passage of time become developed and reinforce the adaption and functioning of an organization. Most of the researches in strategic HRM has paid more attention on these features of planned HRM strategy (see recent literature reviews such as Lepak \& Shaw, 2008), while very little attentiveness is paid on other strand of strategic HRM which analyses how much HR function is involved in management process. In this connection of strategic HRM, HR function is modified from being expert in administration to being a business partner for a very long time and become supportive 
for strategic process because of the ways for the involvement of HR operations in strategic processes pointed in the Ulrich's early strategic HRM model (Lawler \& Mohrman, 2003).

In the systematic plans of management functions, managers find out the methods dynamically to retaliate to problems and provocations in businesses which founds in external environment, through a process of formulation and strategy implementation and increase in the rate of changes (Rivkin \& Gavetti, 2007). HR related goal, practices and policies are affected by the decisions of top managers involved in the strategic formulation of larger processes that emerges from the strategic HRM suggested by Marler (2009). In organization where operational capabilities of dominant HR are administrative expert and these goals help to build a structure of an administration are very limited such tracing the demand of job, managing employee pay cheques beneficial programs and EEO compliance rather than Staff experts busy in the transformation of HR activities like development of HR strategy that work in a better way as a strategic business partner along with strategic product or services (Marler, 2009). Hence in this paper we interpret contribution of strategic HR involvement as professionals HR involvement in policy or strategy development of HRM.

\section{Technological Primacy}

To examine the connection between E-HRM and HR strategy include in decision making is pertinent to various theories describe the relationship between information technology and organizational structure. The structure of an organization impacts on the technological productions used in the firm stated that organizational contingency theory emerged from the studies of organizational technologies (Woodward, 1958). This theory is applied by subsequent research to information technology suggested that an extensive use of information technology produce more decentralised settlement (Leblebici \& Pfeffer, 1977), In making decisions substantial diversification of people participate (Huber, 1990) and more planned or designed execution are adopted by organization (Brynjolfsson \& Hitt, 1997). The reason of underlying this theory is to transform input to output transactions are necessary that uncertainly manages technology (Thompson, 1967) and to reduce uncertainties related to the processes of administration and production that information technology is used primarily (Dewett \& Jones, 2001). Hence, bases on this theory, organizations will gain more success that manages their administrative works by fitting to the capabilities of information technology.

As similar with firm contingency theory, economic theory of neo-classical also state that diffusion of technology compiled with comparative forces because all firms have to perform more systematized or not to get through. Consequently, to the magnitude that increase in yield through new technology as a compliment or as a labor substitute, new technology processes, or cause change in organization. E-HRM is anticipated to accelerate HR productivity by shifting of administrative low value tasks to higher value skilled task. For example, the use of E-HRM digitizes and automates transactional or administrative tasks of HRM, through automating and replacing low value administrative tasks with higher value skilled tasks. E-HRM is expected to increase HR productivity. For example, Allocation of more time to more value able tasks like designing better HR polices for the improvement of organization functions and performance to digitized HR managerial tasks by the use of E-HRM. (Parry \& Tyson, 2007; Marler, 2009). Secondly more comprehensive and effective information which can help the managers in making analytical decisions (Dulebohn \& Johnson, 2013; Hussain, Wallace \& Cornelius, 2007) and planning strategic decisions for an organization should be provided greatly by the use of E-HRM. Third selection of E-HRM is enhanced by both constituting forces and prescriptive pressures (Marler 2009; Paauwe \& Boselie, 2005) in which trader of E-HRM software suggests that their HRM software are built on delivering best HRM practices (Marler, 2009) thus, other mimesis practices are accelerated.

In this competitive world, possibley, firms are using those E-HRM software systems that are accepted as "best practice", (Marler 2009; Paauwe \& Boselie, 2005). The result of adopting the system "best practice" will raise the strategic status of HR managers. In review from various hypothetical perspectives, a transformation in the organization's internal structure enabled by an administrative E-HRM is a technology. Systemize and automation of organizational tasks and assignment of more 
timely and appropriate statistics makes it more efficient and effective to strengthen the contribution of those with information to the use of information technology in a better way for making valuable decisions. Thus, first hypothesis is derived on the base of this contingence theory of information technology that causes changes in organization.

\section{Strategic Primacy}

In contrast, various arguments have been illustrated by some scholars in which strategic decision-making of HR results in the deployment of E-HRM. When a HRM plays planned contribution in decision making of an organization, HRM practices are linked with the strategic management processes of the organization (Wright \& McMahan, 1992). The "linking" procedure between formulation and implementation of strategy represented by planned HRM strategy. Boxall and Purcell (2003) described strategic HRM as a field of study, that is coupled with choices of strategy integrated with the usage of labour in the institution and "discussing reasons why these are more systematized manages by some organizations than others. From this point of view, the advancement of E-HRM may be seen as a strategic alternative as a scheme that empower firm for accomplishing its objective and therefore, a result of HRM having strategic role in an organization (Marler, 2009).

Marler's (2009) practical model, which is ground on the composition of diverse ideas from strategic management, narrates that how planned decisions contribution of HR can predate employment of E-HRM in a firm. HRM managers slogs in establishment and utilizes E-HRM technology for implementing HR practices and development of human capital to support organizational business strategies. In this sense, Martin and Reddington (2010) suggest a framework in which the intention of the of E-HRM system are powered by planned HRM strategic decisions such as decreasing prices and HR headcount and adjustable targets such as captivating a strategic business associate. Marler and Perry (2016) propound that information system of human resources (HRMS) have the potential to be the system through which multinational organizations monitor and locate their employees in order to achieve and assist a competitive advantage. In this association, these assertions hold up the idea that the consequence of strategic HR management is the utilization of E-HRM.

This Second perspective is consistent with a second hypothetical stream of technology literature that is based on the idea of modest constructivism (Leonardi \& Barley, 2007; Kwan \& Tsang, 2001). In this sense, actors in endeavour agencies of an organization over the way in which information technology is bringing into service and some modification that may take place. In this viewpoint of technology, people have their own discretion and are not administer by external forces of technologies. Alternatively, the involvement of all those in progressing and distributive technology structure and how establishment are influenced by, it creates the meaning and reality of technology. E-HRM thus, is upshot of a set of interpretations that originate from a strategy if HRM that is pertain by HRM employee and other functions with its deployment. In this Conceptual framework, participation of HR in setting a firm's strategy is interconnected with conveyance determination such as the level to which HRM practices will be delivered through the use of information technology based on internet such as E-HRM. This paradigm manifests a more dynamic situation or perception of the character played by individuals in the firm, how computer technology is utilized in widespread and notably the active contribution played by strategic HR in how information technology is used carry out strategic goals.

\section{Conclusion}

This review paper underlines some of the important developments in the arena of HRM to understand the contemporary practices. The article has elaborated on the growing shift from HRM to E-HRM and why it is becoming inevitable for businesses to consider it. The discussion has also highlighted features and prospects of E-HRM and its uniqueness in comparison with traditional HRM practices. In parallel, the article also expounds on HRM as a strategic concept whilst unleashing on elements relating to technological primacy. The article aims to serve as a guideline for individuals 
enthusiastic to conduct scholarly work in the area of E-HRM and its strategic importance in the years to come.

\section{References:}

Ahmed, U., Majid, A. H. A., \& Zin, M. L. M. (2016). HR Moderating HR: Critical link between Developmental HR Practices and work engagement in a Moderated Model. Management Review: An International Journal, 11(2), 4-22.

Ahmed, U., Khalid, N., Ammar, A., \& Shah, M. H. (2017). Assessing moderation of employee engagement on the relationship between work discretion, job clarity and business performance in the banking sector of Pakistan. Asian Economic and Financial Review, 7(12), 1197-1210.

Ahmed, U., Phulpoto W., Umrani, W., \& Abbas, S. (2015). Diving deep in employee training to understand employee engagement. Business and Economics Journal, 07(01), 1-4. DOI:10.4172/2151-6219.1000199

Barley, S. R. (1986). Technology as an occasion for structuring: Evidence from observations of CT scanners and the social order of radiology departments. Administrative Science Quarterly, 78-108.

Bondarouk, T. V., \& Ruel, H. J. M. (2009). Electronic Human Resource Management: challenges in the digital era. The International Journal of Human Resource Management, 20(3), 505-514.

Bondarouk, T., Ruël, H. J., \& Parry, E. (Eds.). (2017). Electronic HRM in the Smart Era. Emerald Publishing Limited.

Bower, J. L., \& Christensen, C. M. (1995). Disruptive technologies: catching the wave.

Boxall, P., \& Purcell, J. (2003). Strategy and human resource management: management, work and organisations. Hampshire, Palgrave MacMillan.

Brynjolfsson, E., \& Hitt, L. M. (2000). Beyond computation: Information technology, organizational transformation and business performance. Journal of Economic Perspectives, 14(4), 23-48.

Dewett, T., \& Jones, G. R. (2001). The role of information technology in the organization: a review, model, and assessment. Journal of Management, 27(3), 313-346.

DiMaggio, P. J., \& Powell, W. W. (1983). The iron cage revisited: Institutional isomorphism and collective rationality in organizational fields. American sociological Review, 147-160.

Dulebohn, J. H., \& Johnson, R. D. (2013). Human resource metrics and decision support: A classification framework. Human Resource Management Review, 23(1), 71-83.

Hussain, Z., Wallace, J., \& Cornelius, N. E. (2007). The use and impact of human resource information systems on human resource management professionals. Information \& Management, 44(1), 74-89.

Kwan, K. M., \& Tsang, E. W. (2001). Realism and constructivism in strategy research: A critical realist response to Mir and Watson. Strategic Management Journal, 22(12), 1163-1168.

Lawler, E. E., \& Mohrman, S. A. (2003). HR as a strategic partner: what does it take to make it happen?. Human Resource Planning, 26(3), 15-29.

Leonardi, P. M., \& Barley, S. R. (2008). Materiality and change: Challenges to building better theory about technology and organizing. Information and Organization, 18(3), 159-176.

Lepak, D. P., \& Shaw, J. D. (2008). Strategic HRM in North America: looking to the future. The International Journal of Human Resource Management, 19(8), 1486-1499.

Lepak, D. P., \& Snell, S. A. (1998). Virtual HR: Strategic human resource management in the 21st century. Human Resource Management Review, 8(3), 215-234.

Liang, X., Marler, J. H., \& Cui, Z. (2012). Strategic human resource management in China: east meets west. Academy of Management Perspectives, 26(2), 55-70.

Marler, J. H., \& Fisher, S. L. (2013). An evidence-based review of e-HRM and strategic human resource management. Human Resource Management Review, 23(1), 18-36. 
Marler, J. H., \& Parry, E. (2016). Human resource management, strategic involvement and e-HRM technology. The International Journal of Human Resource Management, 27(19), 2233-2253.

Martin, G., \& Reddington, M. (2010). Theorizing the links between e-HR and strategic HRM: a model, case illustration and reflections. The International Journal of Human Resource Management, 21(10), 1553-1574.

Martin, G., \& Reddington, M. (2010). Theorizing the links between e-HR and strategic HRM: a model, case illustration and reflections. The International Journal of Human Resource Management, 21(10), 1553-1574.

Orlikowski, W. J., \& Scott, S. V. (2008). 10 sociomateriality: challenging the separation of technology, work and organization. The Academy of Management Annals, 2(1), 433-474.

Paauwe, J., \& Boselie, P. (2005). HRM and performance: what next?. Human Resource Management Journal, 15(4), 68-83.

Parry, E., Tyson, S., Selbie, D., \& Leighton, R. (2007). HR and technology: Impact and advantages. London: Charted Institute of Personnel and Development.

Pfeffer, J., \& Leblebici, H. (1977). Information technology and organizational structure. Pacific Sociological Review, 20(2), 241-261.

Shrivastava, S., \& Shaw, J. B. (2003). Liberating HR through technology. Human Resource Management: Published in Cooperation with the School of Business Administration, The University of Michigan and in alliance with the Society of Human Resources Management, 42(3), 201-222.

Strohmeier, S. (2007). Research in e-HRM: Review and implications. Human Resource Management Review, 17(1), 19-37.

Thompson, E. P. (1967). Time, work-discipline, and industrial capitalism. Past E present, (38), 56-97.

Woodward, J. (1958). Management and Technology (No. 3). HM Stationery Off.

Wright, P. M., \& McMahan, G. C. (1992). Theoretical perspectives for strategic human resource management. Journal of Management, 18(2), 295-320.

Wright, P. M., \& McMahan, G. C. (1992). Theoretical perspectives for strategic human resource management. Journal of Management, 18(2), 295-320.

(C) 2019 by the author(s). Published by Annals of Contemporary Developments in Management \& HR (ACDMHR), under the terms and conditions of the Creative Commons Attribution (CC BY) license which can be accessed at http://creativecommons.org/licenses/by/4.0/. 